\title{
Evaluation of biological and physicochemical risk of hospital liquid waste in Morocco
}

\author{
B.Sarhane ${ }^{1}$, A. Tantane ${ }^{2}$, O. El Rhaouat ${ }^{3}$, A. El Ouardi ${ }^{4}$, K. El Kharrim ${ }^{5}$, D. Belghyti ${ }^{6}$ \\ ${ }^{1,2,4}$ Department of Water Microbiology and Food Hygiene, National Institute of Hygiene, Rabat, Morocco, \\ 1,3,5,6 Laboratory of Agrophysiology, Biotechnology, Environment and Quality. University IbnTofail, Faculty of \\ Science, BP 133, Morocco. \\ Corresponding author: sarhane_bouchaib@yahoo.fr
}

\begin{abstract}
Hospitals could be the source of pollution that must be taken into account in a general approach to health and environmental risk assessment. This study is part of the characterization of hospital liquid waste in a region in Morocco, whose objective is to assess their physicochemical, bacteriological and toxicological quality.
\end{abstract}

The physicochemical analyzes carried out on 144 samples taken during one year showed a great fluctuation of some parameters such as: BOD5, COD, MES, $P H, T^{\circ}$, as well as an important bacteriological load: Total coliforms, E coli, faecal Streptococci, pathogenic germs such as: Salmonella, Staphylococcus, $20 \%$ multi-resistant, virulent germs of emerging nature such as: Pseudomonas aeroginosa, and trace metal elements such as: mercury and copper that exceed the threshold of acceptability. At the end of this study, it turned out that hospital effluents are heavily loaded with pollutants. We therefore hope, in the light of the results provided by this study, to have generated a real awareness of the competent authorities on strengthening and improving the treatment of hospital liquid effluents such as developed countries, as the impact of these effluents on human and environmental health is harmful and can spread emerging diseases.

Keywords — Wastewater, Liquid effluent, physicochemical pollution, bacteriological, trace elements.

\section{INTRODUCTION}

All human activity generates solid and liquid waste. The numerous studies carried out in recent years on the sectors and methods of disposal of solid waste have demonstrated the interest that health and administrative professionals in hospitals and the public authorities attach to this subject in particular, and to the protection of the environment and public health in general. This awareness appeared concomitantly with new micro-organisms (viruses, multi-resistant bacteria and prions) and evolved with the progress of medical techniques and the application of aseptic rules associated with the extension the use of unique uses.

Hospital centers whose size corresponds to small or medium-sized agglomerations use for their activities and hygiene, large volumes of water which are then rejected, loaded with microorganisms, some of which are multi-resistant and often toxic chemicals and sometimes radioactive. This study shows that health care institutions must master the management and treatment of their liquid waste. [1],[2],[3],[4],[5],[6],[7],[8],[9],[10].

\section{MATERIALS AND MethodS}

As sampling sites for this study were selected specific manifolds in two major hospitals: The collectors of the hospital 1:The kitchen collector;- The manifold that connects the emergency services and traumatology; the manifold that connects lingerie and laboratory;- The collector of motherhood. The collectors of the hospital 2- The main collector; - Emergency collector. Sampling of liquid effluent two hospitals under study was performed six times a season and three times a day at the outlets of the collectors of sewage chosen over a period of a year, for a total of 144 samples. The samples were held in the flow area of the sewer where water movement is most active. Samples of releases have been made according to Moroccan standards. The analyzes were performed at the National Institute of Hygiene. The desired parameters: Physicochemical: T, PH, Cond, COD, BOD5, TSS, ... Metallic trace elements: $\mathrm{Hg}, \mathrm{Cd}, \mathrm{Cr}, \mathrm{Cu}, \mathrm{Pb}$;Microbiological: contamination germs Fecal (coliforms,

E. coli ...) germs pathogens (Salmonella, Vibrio, ...), germs of hospital origin (Pseudomonas, Staphylococcus aureus, Enterococci intestinal, ...)Microbiological analyzes were performed by the membrane filtration method according Moroccan standards. The analyzes of trace metals were made by atomic adsorption spectrophotometry electrothermal furnace with graphite VARIAN.240 Type (GF-AAS) for the lead, copper, chromium, and cadmium. The temperature, $\mathrm{pH}$ and conductivity 
were measured on site using a mobile ph-meter HANNA type of direct readout and type conductivity CONSORT 535 expressed in microseconds $/ \mathrm{cm}$.

\section{RESUlTS}

\subsection{Physicochemical parameters:}

\subsubsection{Electrical conductivity}

The mean value of the conductivity is 1500 microseconds / $\mathrm{cm}$ in the rejection of the maternity hospital1.This is due to the misuse of detergents and ionizing injections [11]. This class value release to category 3 (release quality grid); [14].

\section{TABle 1}

TEMPORAL VARIATION OF ELECTRICAL CONDUCTIVITY AS A FUNCTION OF TIME

\begin{tabular}{|c|c|c|c|c|c|c|c|}
\hline & & \multicolumn{4}{|c|}{ Hospital 1} & \multicolumn{2}{|c|}{ Hospital 2} \\
\hline \multirow{7}{*}{ 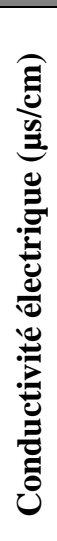 } & & Emergency+Traumatology & Maternity & Laboratory+Lingerie & Kitchen & Mainrejection & $\begin{array}{l}\text { Rejection of } \\
\text { emergencies }\end{array}$ \\
\hline & Winter & 767,67 & 1546,33 & 1323,67 & 1323,66 & 926,33 & 1249,33 \\
\hline & Spring & 767,67 & 1521 & 1328 & 1387,67 & 928,33 & 1251,33 \\
\hline & Summer & 759 & 1511,33 & 1348 & 1381 & 923,66 & 1247,66 \\
\hline & Autumn & 762,33 & 1535,33 & 1348,67 & 1385,33 & 928 & 1252,33 \\
\hline & Mean & 763 & 1536,19 & 1337,085 & 1385 & 926,58 & 1250,1625 \\
\hline & STDEV & 3,571 & 18,097 & 13,113 & 2,881 & 2,134 & 2,083 \\
\hline
\end{tabular}

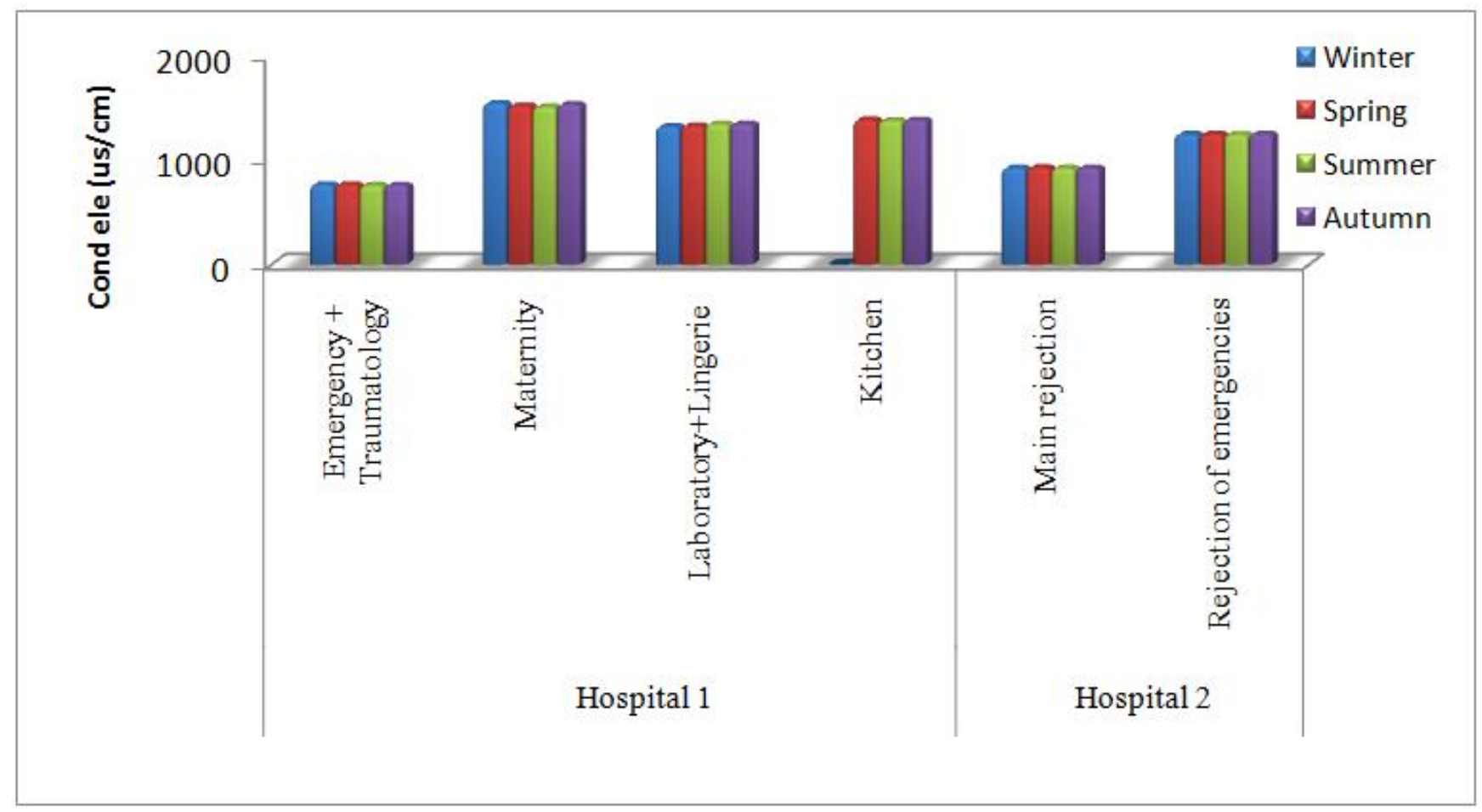

\section{Fig 1: CHANGE IN ELECTRICAL CONDUCTIVITY DEPENDING ON THE SEASON}

\subsubsection{Turbidity:}

The measurement of turbidity makes it possible to specify the visual information on the water. Turbidity indicates the presence of particles suspended in water (organic debris, clays, microscopic organisms, etc.). 
TABLE 2

MEASUREMENT OF THE TURBIDITY OF HOSPITAL EFFLUENTS IN THE HYDROLOGY LABORATORY - INH RABAT

\begin{tabular}{|c|c|c|c|c|c|c|c|}
\hline & \multicolumn{5}{|c|}{ Hospital 1} & \multicolumn{2}{|c|}{ Hospital 2} \\
\hline \multirow{7}{*}{ 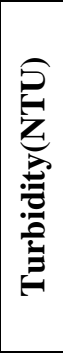 } & & $\begin{array}{c}\text { Emergency + } \\
\text { Traumatology }\end{array}$ & Maternity & Laboratory+Lingerie & Kitchen & $\begin{array}{c}\text { Main } \\
\text { rejection }\end{array}$ & $\begin{array}{l}\text { Rejection of } \\
\text { emergencies }\end{array}$ \\
\hline & Winter & 18,82 & 178,19 & 194,12 & 13 & 46,36 & 86,12 \\
\hline & Spring & 18,82 & 170,9 & 193,93 & 12,63 & 46,07 & 178,33 \\
\hline & Summer & 18,91 & 177,07 & 192,8 & 12,22 & 47,33 & 70,73 \\
\hline & Autumn & 18,9 & 177,47 & 192,83 & 12,46 & 47 & 70,5 \\
\hline & Mean & 18,86 & 175,91 & 193,42 & 12,57 & 46,69 & 101,42 \\
\hline & STDEV & 0,049 & 3,37 & 0,703 & 0,328 & 0,577 & 51,792 \\
\hline
\end{tabular}

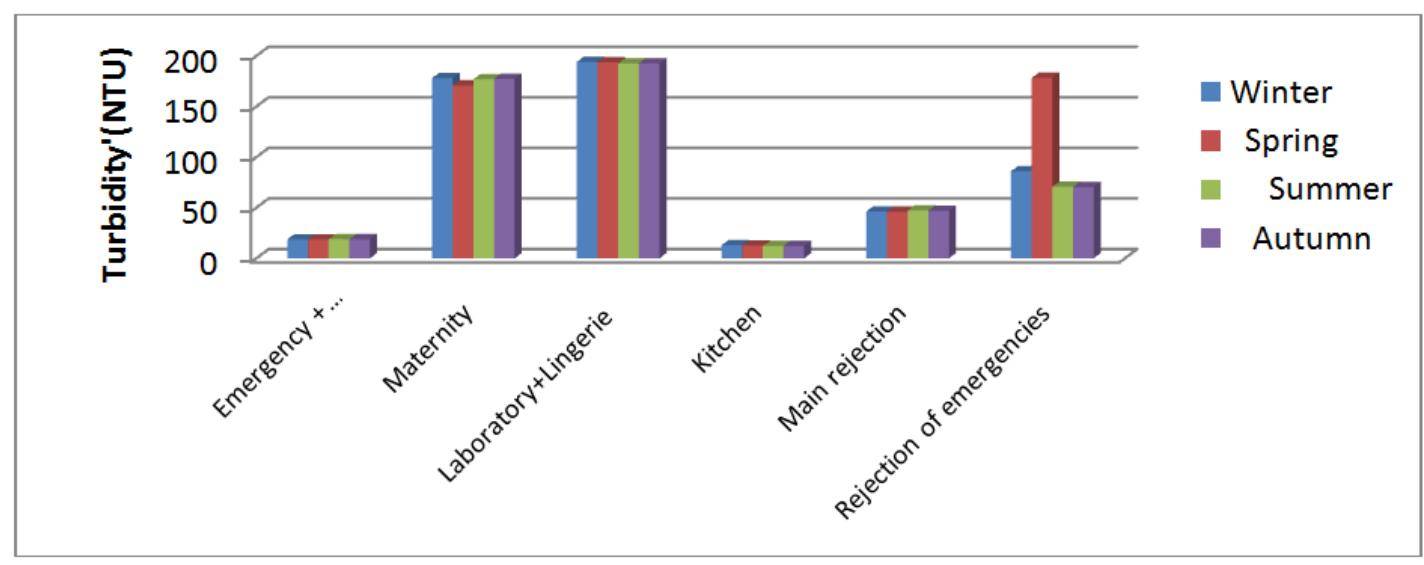

\section{FIG 2: CHANGE IN TURBIDITY BY SEASON}

The average value of turbidity is between 18 and 194 NTU (maximum value observed in laboratory collectors and lingerie to the hospital1).This prevents the propagation of light; therefore the hospital sewage clarification is necessary.

\subsubsection{COD / BOD5:}

TABLE: 3

REPORT EVALUATIONS FOLLOW SAMPLING SITES

\begin{tabular}{|c|c|c|c|c|c|c|c|}
\hline & \multicolumn{5}{|c|}{ Hospital 1} & \multicolumn{2}{|c|}{ Hospital 2} \\
\hline \multirow{5}{*}{ 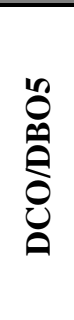 } & & $\begin{array}{c}\text { Emergency + } \\
\text { Traumatology }\end{array}$ & Maternity & Laboratory+Lingerie & Kitchen & Main rejection & $\begin{array}{l}\text { Rejection of } \\
\text { emergencies }\end{array}$ \\
\hline & $9 \mathrm{H} 30$ & 7,75 & 3,98 & 7,98 & 7,02 & 8,02 & 8,09 \\
\hline & $11 \mathrm{H} 40$ & 7,19 & 4,01 & 7,89 & 6,81 & 8 & 7,99 \\
\hline & $13 \mathrm{H} 30$ & 6,27 & 3,97 & 7,9 & 6,77 & 7,98 & 7,92 \\
\hline & Moyenne & 7,07 & 3,99 & 7,92 & 6,87 & 8 & 8 \\
\hline
\end{tabular}


The average values for the period of samples for the six releases of the two hospitals are between 6.5 and $8.21 \mathrm{mg} / \mathrm{L}$, indicating poor biodegradability due to the chemical nature of hospital discharges

\subsection{Metalic trace elements:}

$>$ Mercury (Hg): Mercury concentrations are ten times the threshold value $(0.05 \mathrm{mg} / 1)$.This is due to the frequent use of mercury thermometers at the hospital and the use of mercury-based detergents.

$>$ Copper $(\mathrm{Cu})$ : Copper reached $531.02 \mathrm{mg} / \mathrm{l}$ during the fall season for six of the two hospitals sampling sites; the concentration increase is mainly due to the use of reagents and chemicals in hospitals.

\subsection{Bacteriological parameters:}

\subsubsection{Microbiological indicators of faecal contamination}

The maximum value of E. coli was noticed during the period of high activity of hospital services, this indicates recent faecal contamination.

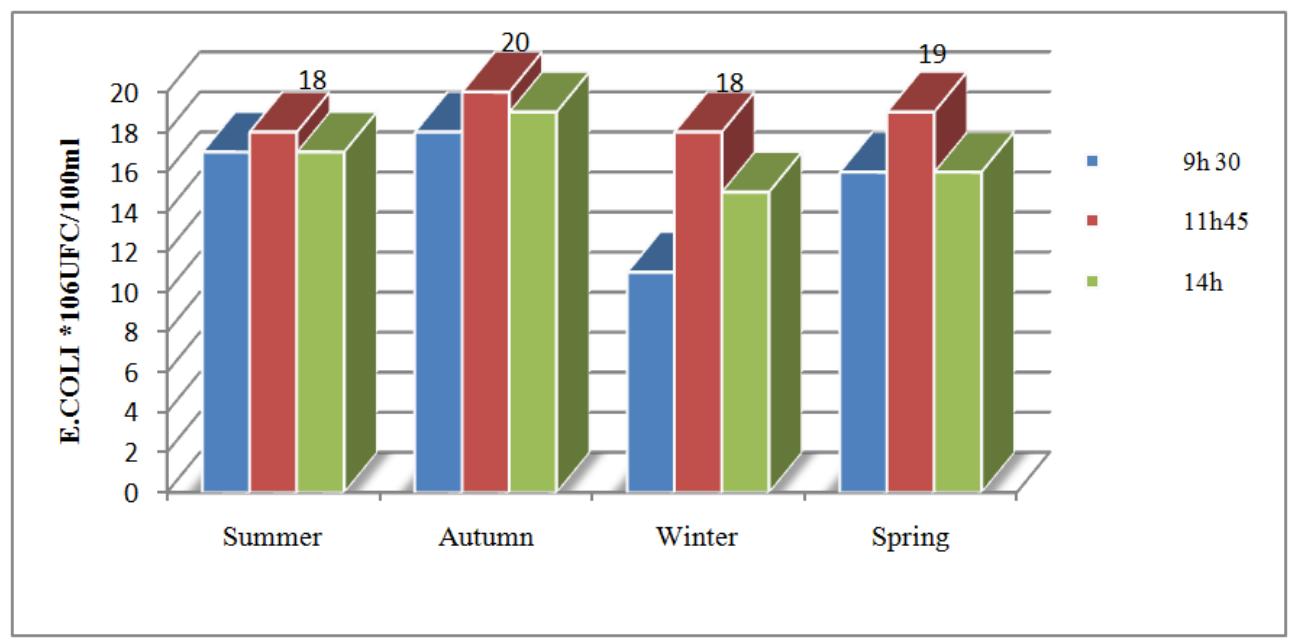

Fig 4: TEMPORAL VARIATION IN ESCHERICHIA COLI

\subsubsection{Pathogens}

The burden of Staphylococcus aureus increases during the summer, especially during the period of high activity (11h $45 \mathrm{~min}$ ). The load reaches $4.510^{6} \mathrm{CFU} / 100 \mathrm{ml}$.

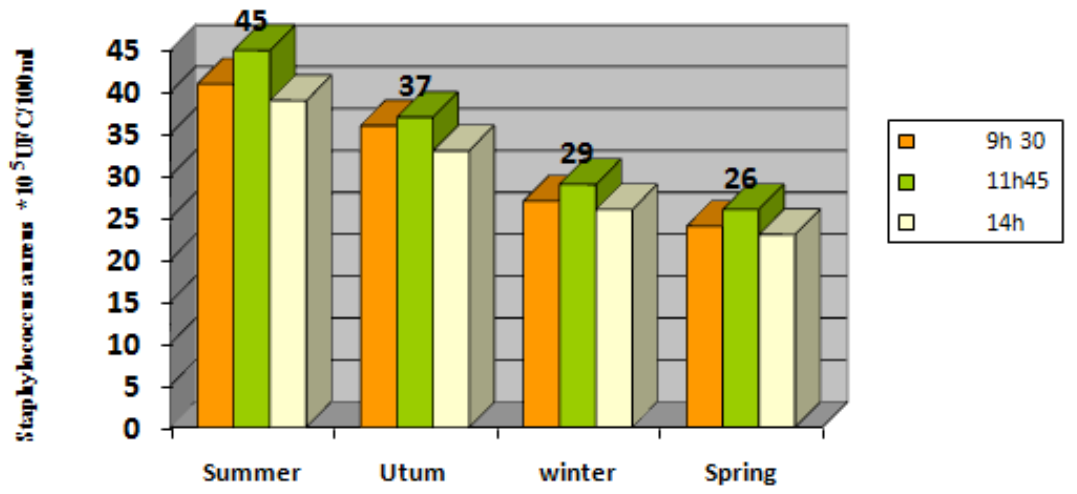

FIG 5: TEMPORAL VARIATION IN STAPHYLOCOCCUS AUREUS

\subsection{Virulent germs}

Eight Salmonella have been identified in the main collectors and emergency hospital 2: Salmonella Chester, entertidis (MDR) and 2 Salmonella (MDR) in the collectors of the hospitall. and 2 Vibrio parahaemolyticus were isolated in the releases of the two hospitals for specific CHROMagar Vibrio and poly monovalent and serology. 


\section{CONCLUSION}

The results of the analyzes we have done during one year showed that the hospital effluents have a high rate of pollution both physicochemical, biological and toxicological; Indeed test results exceeded the thresholds set by national standards of direct and indirect discharges [14], and could have a detrimental effect on the health of the population of the study area and its direct environment. Indeed, the concentration of BOD5 ( $259.55 \mathrm{mg} / 1$ ) classifies liquid discharges from two hospitals as standards ( quality Grid ) in the category of poor quality. The results of toxicology tests showed values above the threshold allowed by legislation and national and international standards, such as: Mercury: $0.9 \mathrm{mg} / \mathrm{l}$ in the rejection of Traumatology and Emergency $+0.8 \mathrm{mg} / 1$ in maternity, This is due to the misuse of mercury thermometers that are banned in France referring to Jehanin and the use of some mercury-based detergents; Copper: 500 times exceeds the normative limit indirect discharges These two heavy metals have a harmful effect on health and the environment: Mercury is a cumulative poison that causes neurological disorders, gingivitis and stomatitis, as well as kidney damage. In the environment, it turns into organomercury $(\mathrm{CH} 3 \mathrm{Hg}+)$ that pass the placental barrier causing teratogenic and fetotoxic; Copper causes an alteration of fish gills, and a greening effect oysters, it becomes toxic when complexed with the organic matter. Other physico-chemical analyzes of wastewater two hospitals showed that the values of $\mathrm{PH}$ obtained belong to the favorable $\mathrm{PH}$ area development of most microorganisms. The $\mathrm{pH}$ value varies between 6.02 and 7, 43, and the temperature is below $30^{\circ} \mathrm{C}$. This explains the indicators of fecal contamination obtained show an increasing trend throughout the study. Indeed, the maximum concentration of the medium during the CT seasons is $43.10^{7} \mathrm{UFC} / 100 \mathrm{ml}$ and that E. coli is $19.10^{6} \mathrm{UFC} / 100 \mathrm{ml}$. Moreover, the most contaminated sites in the most pathogenic bacteria such as Salmonella are, emergency trauma + , the main rejection and motherhood. These bacteria are highly virulent and have a high impact on the health of the population and the spread of epidemic diseases.

\section{REFERENCES}

[1] CTC, 1994: Clean Technology Consultant 1994. Design Criteria of Wastewater Treatment Plant, Ratchawithi Hospital, Bangkok, Thailand.

[2] Wangsaatmaja, 1997; Wangsaatmaja, S., 1997. Environmental Action Plan for a Hospital, MS Thesis in Engineering, Asian Institute of Technology, Bangkok, Thailand.

[3] Laber et al., 1999 ; Laber, J., Haberl, R., Shrestha, R., 1999. Two stage constructed wetland for treating hospital wastewater in Nepal. Water Sci. Technol. 40 (3), 317-324.

[4] Chawatee, 2002; Chawatee, S.D., 2002. Manual on Water Demand Assessment for Urban WaterSupply Projects, Indian Water Works Association

[5] Altin et al., 2003; Altin, A., Altin, S., Degirmenci, M., 2003. Characteristics and treatability of hospital (medical) wastewaters. Fresen. Environ. Bull. 12 (9), 1098-1108

[6] Mohee, 2005; Mohee, R., 2005. Medical wastes characterisation in healthcare institutions in Mauritius. Waste Manage. 25, 575-581

[7] Rezaee et al., 2005; Rezaee, A., Ansari, M., Khavanin, A., Sabzali, A., Aryan, M.M., 2005. Hospital wastewater treatment using an integrated anaerobic aerobic fixed filmbioreactor. Am. J. Environ. Sci. 1 (4), 259-263.

[8] Sarafraz, S., Khani, M., Yaghmaeian, K., 2007. Quality and quantity survey of hospital wastewater in hormozgan Province. Iran. J. Health Sci. Eng. 4 (1), 43-50.

[9] Duong and al 2008. Occurrence, fate and antibiotic resistance of fluoroquinolone antibacterials in hospital wastewater sin Hanoi, Vietnam. Chemosphere 72, 968-973.

[10] Emmanuel E., Doctoral thesis, National Institute of Applied Sciences of Lyon, (2004) 245-246.

[11] Belghyti D., Elguamri Y., Ztit G., My Ouahidi L., My brahim J., Harchrass A., Amghar H, Bouchouata O ., El kharrim K., Bounouira H. Caractérisation physico-chimique des eaux usées d'abattoir en vue de la mise en oeuvre d'un traitement adéquat : cas de Kénitra au Maroc, Afrique Science 05(2), pp 153 - 216, 2009.

[12] ONEP., Approche de la typologie des eaux usées urbaines au Maroc. ONEP et GTZ. Rabat, 1998.

[13] WHO, "Water and Sanitation: Aide Memoire No. 112, Press Releases," 1996.

[14] CNS, 1994: surface water quality grid. 1994. 